\title{
Microcyclic rusts of hollyhock (Alcea rosea)
}

\author{
Jill E. Demers ${ }^{1}$, Megan K. Romberg ${ }^{2}$, and Lisa A. Castlebury ${ }^{1 *}$
}

1USDA-ARS, Systematic Mycology and Microbiology Laboratory, Beltsville, MD 20705, USA; corresponding author e-mail: Jill.Demers@ARS. USDA.GOV

${ }^{2}$ USDA-APHIS-PPQ-National Identification Services, Beltsville, MD 20705, USA

\begin{abstract}
Rust fungi infecting hollyhock and other plants in Malveae are frequently intercepted at ports of entry to the USA, particularly Puccinia malvacearum and $P$. heterogenea. These two species can be difficult to distinguish and can be further confused with other, less common species of microcyclic rust fungi infecting hollyhock: $P$. heterospora, $P$. lobata, P. platyspora, and $P$. sherardiana. Molecular phylogenetic analysis revealed that $P$. malvacearum and $P$. heterogenea are closely related, along with $P$. sherardiana and $P$. platyspora. A key to the six microcyclic Puccinia species infecting hollyhock is presented.
\end{abstract}

Key words:
Pucciniales
Puccinia
pathogen interceptions
identification
taxonomy

Article info: Submitted: 29 September 2015; Accepted: 16 November 2015; Published: 20 November 2015.

\section{INTRODUCTION}

Plants and plant products imported into the USA are inspected at ports of entry for pests including insects, mollusks, nematodes, bacteria, and fungi (McCullough et al. 2006). Plant pests that are found during inspections may be barred from entering the USA depending on their risk to agriculture and natural ecosystems and whether the pests are already established within the country. Some frequently imported plants include species of Malvoideae, the mallow subfamily that includes economically important plants such as cotton (Gossypium hirsutum), kenaf (Hibiscus cannabinus), okra (Abelmoschus esculentus), and many ornamental plants including hollyhock (Alcea rosea) (Baum et al. 2004). Alcea rosea, a plant grown worldwide, is often intercepted at ports of entry infected with rust fungi.

Many rust fungi can infect $A$. rosea. Six species of Puccinia have been reported to produce telia on $A$. rosea: $P$. heterogenea, $P$. heterospora, $P$. lobata, $P$. malvacearum, $P$. platyspora, and $P$. sherardiana (Arthur 1922, Lindquist 1982, Farr \& Rossman 2015). All of these species are microcyclic and do not produce uredinia or aecia, have no known alternate hosts, and produce both one-celled and two-celled teliospores with different spore morphologies predominating in different species (Arthur 1922, Lindquist 1982). Another two species of Puccinia, $P$. interveniens and $P$. schedonnardi, are reported to produce aecia on $A$. rosea, and $A$. rosea is also reported to be infected by two other rust fungi, Endophyllum tuberculatum and Kuehneola malvicola (Arthur 1934, Farr

\footnotetext{
* Mention of trade names or commercial products in this publication is solely for the purpose of providing specific information and does not imply recommendation or endorsement by the U.S. Department of Agriculture. USDA is an equal opportunity provider and employer.
}

\& Rossman 2015). Of these fungi, $P$. malvacearum is the most widely reported (Farr \& Rossman 2015) and the most frequently intercepted at US borders. Puccinia malvacearum has been reported worldwide on a large number of hosts in Malvoideae, primarily in tribe Malveae, including the genera Abutilon, Alcea, Anoda, Hibiscus, Lavatera, Malva, Malvastrum, Pavonia, Sida, and Sidalcea (Farr \& Rossman 2015). Puccinia heterogenea, although less commonly reported than $P$. malvacearum, has also been intercepted at US ports of entry multiple times. Puccinia heterogenea has only been reported from Ecuador and Peru on hosts in Alcea, Malva, and Fuertesimalva (Farr \& Rossman 2015) but is morphologically similar to $P$. malvacearum and frequently misidentified.

In this study, $P$. malvacearum, $P$. heterogenea, and the other microcyclic rusts on $A$. rosea, $P$. heterospora, $P$. lobata, $P$. platyspora, and $P$. sherardiana, were characterized morphologically and the LSU rDNA region was sequenced. These data are presented as a guide to identification of the rusts of $A$. rosea. In addition, the phylogenetic placement of these six Puccinia species was determined.

\section{MATERIALS AND METHODS}

Specimens for this study were obtained from interceptions at US borders and from reference material, from the years 1890 to 2015 . Morphological features of all specimens were characterized, and measurements were made using Zeiss AxioVision SE64 4.9.1 software (Carl Zeiss Microscopy, Jena). A minimum of 20 spores was examined from each specimen, with multiple specimens examined per species. DNA was extracted from small (approximately $0.5-1 \mathrm{~cm}^{2}$ ) leaf fragments containing telia using the Qiagen DNeasy Plant Mini kit (Gaithersburg, MD). PCRs were done using the KAPA2G Robust PCR kit (Wilmington,

Cㅇ 2015 International Mycological Association

You are free to share - to copy, distribute and transmit the work, under the following conditions:

Attribution: $\quad$ You must attribute the work in the manner specified by the author or licensor (but not in any way that suggests that they endorse you or your use of the work).

Non-commercial: $\quad$ You may not use this work for commercial purposes.

No derivative works: You may not alter, transform, or build upon this work.

For any reuse or distribution, you must make clear to others the license terms of this work, which can be found at http://creativecommons.org/licenses/by-nc-nd/3.0/legalcode. Any of the above conditions can be waived if you get permission from the copyright holder. Nothing in this license impairs or restricts the author's moral rights. 
MA), following the manufacturer's suggested protocol. A portion of the LSU rDNA gene was amplified using two overlapping primer sets, LROR (5'-GTACCCGCTGAACTTAAGC-3'; http:// sites.biology.duke.edu/fungi/mycolab/primers.htm) and PucLSUr (5'-GCTTACTGCCTTCCTCAATCT-3'; designed by JED in this study), andLR5(5'-ATCCTGAGGGAAACTTC-3'; Vilgalys\&Hester 1990) and PucLSUf (5'-TGGGTGTTGGAGAAGGGTTT-3'; designed by JED in this study). Host identifications of reference material were made by the original collector based on morphology and confirmed at the generic level using rDNA ITS2 sequences. Some intercepted plants could not be identified based on morphology due to the small size of the specimens, and identification was then based solely on plant ITS2 sequences. Host ITS2 sequences were amplified with the primers ITS4 (5'-TCCTCCGCTTATTGATATGC-3'; White et al. 1990) and ITS2S2F (5'-ATGCGATACTTGGTGTGAAT-3'; Chen et al. 2010). Amplifications for all primer sets were performed using the conditions $94{ }^{\circ} \mathrm{C}$ for $2 \mathrm{~min}$, followed by 36 cycles of $94{ }^{\circ} \mathrm{C}$ for $30 \mathrm{~s}$, annealing temperature for $30 \mathrm{~s}$, and $72{ }^{\circ} \mathrm{C}$ for $30 \mathrm{~s}$, followed by $10 \mathrm{~min}$ at $72{ }^{\circ} \mathrm{C}$, with annealing temperatures of $53^{\circ} \mathrm{C}$ for PucLSUf/LR5, $55^{\circ} \mathrm{C}$ for ITS4/ITS2S2F, and $58{ }^{\circ} \mathrm{C}$ for LROR/PucLSUr. Sequencing was performed using the BigDye Terminator v. 3.1 cycle sequencing kit (Life Technologies, Grand Island, NY), and reactions were run on an Applied Biosystems 3130xI Genetic Analyzer (Life Technologies, Grand Island, NY). Sequences were edited with Sequencher v. 5.0 (Gene Codes Corp., Ann Arbor, MI) and aligned with MAFFT v. 7 (Katoh \& Standley
2013). Maximum likelihood trees were inferred using RAxML BlackBox (Stamatakis et al. 2008).

\section{RESULTS}

Both Puccinia malvacearum and $P$. heterogenea were commonly intercepted at ports of entry into the USA between 1950 and 2015. Puccinia malvacearum was frequently intercepted on Alcea rosea, but also on Malva arborea, $M$. multiflora, $M$. neglecta, $M$. nicaeensis, and $M$. sylvestris. Puccinia heterogenea was intercepted less often than $P$. malvacearum, although still intercepted multiple times, and was primarily found on $M$. arborea, as well as on $A$. rosea. Other rust fungi intercepted on $A$. rosea were $P$. heterospora, $P$. lobata, and $P$. sherardiana.

LSU sequences were generated for 29 specimens of rust fungi on Malveae (GenBank accession nos. KT827287-KT827315). Phylogenetic analysis revealed that $P$. malvacearum, $P$. heterogenea, $P$. sherardiana, and $P$. platyspora are closely related to each other in one clade (Fig. 1). No other species of rust fungi were identified in that clade, based on LSU sequences available in GenBank. Little intra-specific variation was found among specimens of $P$. malvacearum and $P$. heterogenea, while a high degree of intra-specific variation was found within $P$. heterospora as compared to the other rust fungi infecting $A$. rosea.

\section{TAXONOMY}

\section{Key to the microcyclic rusts of hollyhock}

2 (1) One-celled teliospores mostly $<25 \mu \mathrm{m}$ in length, globose

Puccinia heterospora

One-celled teliospores mostly $>25 \mu \mathrm{m}$ in length, ovoid to oblong 3

3 (2) Teliospores with apical walls to $13 \mu \mathrm{m}$ thick

Puccinia platyspora Teliospores with apical walls to $5 \mu \mathrm{m}$ thick Puccinia heterogenea

4 (1) Telia light reddish brown, scattered Puccinia malvacearum Telia dark brown, in clusters 5

5 (4) Two-celled teliospores with no or little central constriction Puccinia lobata Two-celled teliospores with a central constriction Puccinia sherardiana

Puccinia heterospora Berk. \& M. A. Curtis, Bot. J. Linn. Soc. 10: 356 (1869). (Figs 2-3)

Description: Telia dark brown, mainly hypophyllous, in tight clusters. Teliospores light brown to reddish-brown, predominately one-celled. One-celled teliospores globose, highly variable in size, $17-30 \times 15-29 \mu \mathrm{m}$, on average $21 \times 19$ $\mu \mathrm{m}$. Two-celled teliospores globose to oblong, frequently have septa perpendicular to the pedicel attachment point; length of the two-celled teliospores parallel to pedicel attachment point (17-35 $\mu \mathrm{m}$, on average $22 \mu \mathrm{m}$ ) often shorter than the length of the spores perpendicular to the pedicel attachment point (16-34 $\mu \mathrm{m}$, on average $20 \mu \mathrm{m}$ ). Side walls of teliospores 1.5-3 $\mu \mathrm{m}$ thick, apical walls $3-7 \mu \mathrm{m}$ thick. Pedicels hyaline, to 100 $\mu \mathrm{m}$ long.

Specimens examined: Argentina: Tucuman Province: San Miguel de Tucuman, on Anoda cristata, 23 Jun. 1995, J. R. Hernandez (BPI 863576). - Intercepted specimens (origin unknown): Intercepted 


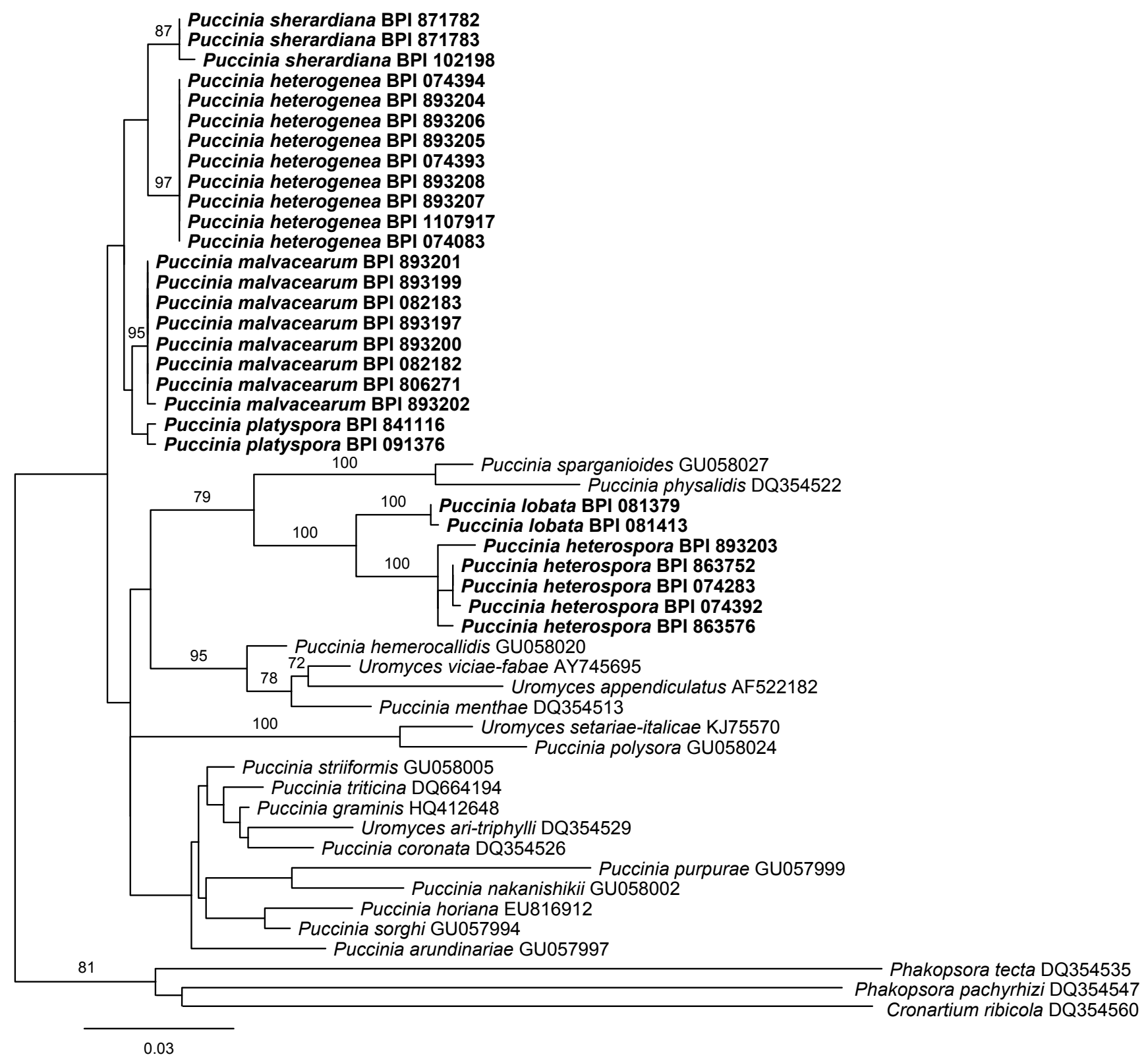

Fig. 1. Most likely phylogenetic tree of the microcyclic rusts infecting Malveae (in bold). Likelihood values $\geq 70 \%$ are shown above branches. The tree is rooted with Phakopsora tecta, Phakopsora pachyrhizi, and Cronartium ribicola.

at Brownsville, Texas, entering from Mexico, on Alcea rosea, 2 Feb. 1950, Gayden (BPI 074286); Intercepted at Brownsville, Texas, entering from Mexico, on Alcea rosea, 12 Mar. 1950, C. B. Brown (BPI 074283); Intercepted at Brownsville, Texas, entering from Mexico, on Abutilon trisulcatum, 25 Dec. 1951, G. A. Pfaffman (BPI 074275); Intercepted at El Paso, Texas, entering from Mexico, on Sida sp., 25 Aug. 2003, M. A. Mendoza (BPI 893203). - Mexico: Veracruz: El Higo, on Abutilon trisulcatum, 13 Dec. 2003, J. R. Hernandez (BPI 863752).

Puccinia platyspora (Speg.) H. S. Jacks. \& Holw., Mycologia 23: 480 (1931).

(Figs 2-3)

Description: Telia reddish brown, hypophyllous, scattered. Teliospores yellowish brown, often with apical pores or split walls at the apices, predominately one-celled; some two- celled teliospores with very thin septa or partial septa. Onecelled teliospores 34-53 $\times 15-22 \mu \mathrm{m}$, on average $42 \times 17$ $\mu \mathrm{m}$. Two-celled teliospores 34-57 $\times 13-21 \mu \mathrm{m}$, on average $46 \times 16 \mu \mathrm{m}$. Side walls of teliospores $1.5-2 \mu \mathrm{m}$ thick, apical walls $3-13 \mu \mathrm{m}$ thick. Pedicels hyaline, to $70 \mu \mathrm{m}$ long.

Specimens examined: Argentina: La Falda, on Sphaeralcea sp., 21 Aug. 1922, E. W. D. \& M. M. Holway (BPI 091376); Jujuy Province: Tilcara, on Alcea rosea, 3 Feb. 1996, J. R. Hernandez (BPI 841116).

Puccinia heterogenea Lagerh., J. Mycol. 7: 44 (1891). (Figs 2-3)

Description: Telia dark reddish brown, mainly hypophyllous, scattered. Teliospores yellowish brown, often with apical pores or split walls at the apices; one- and two-celled 

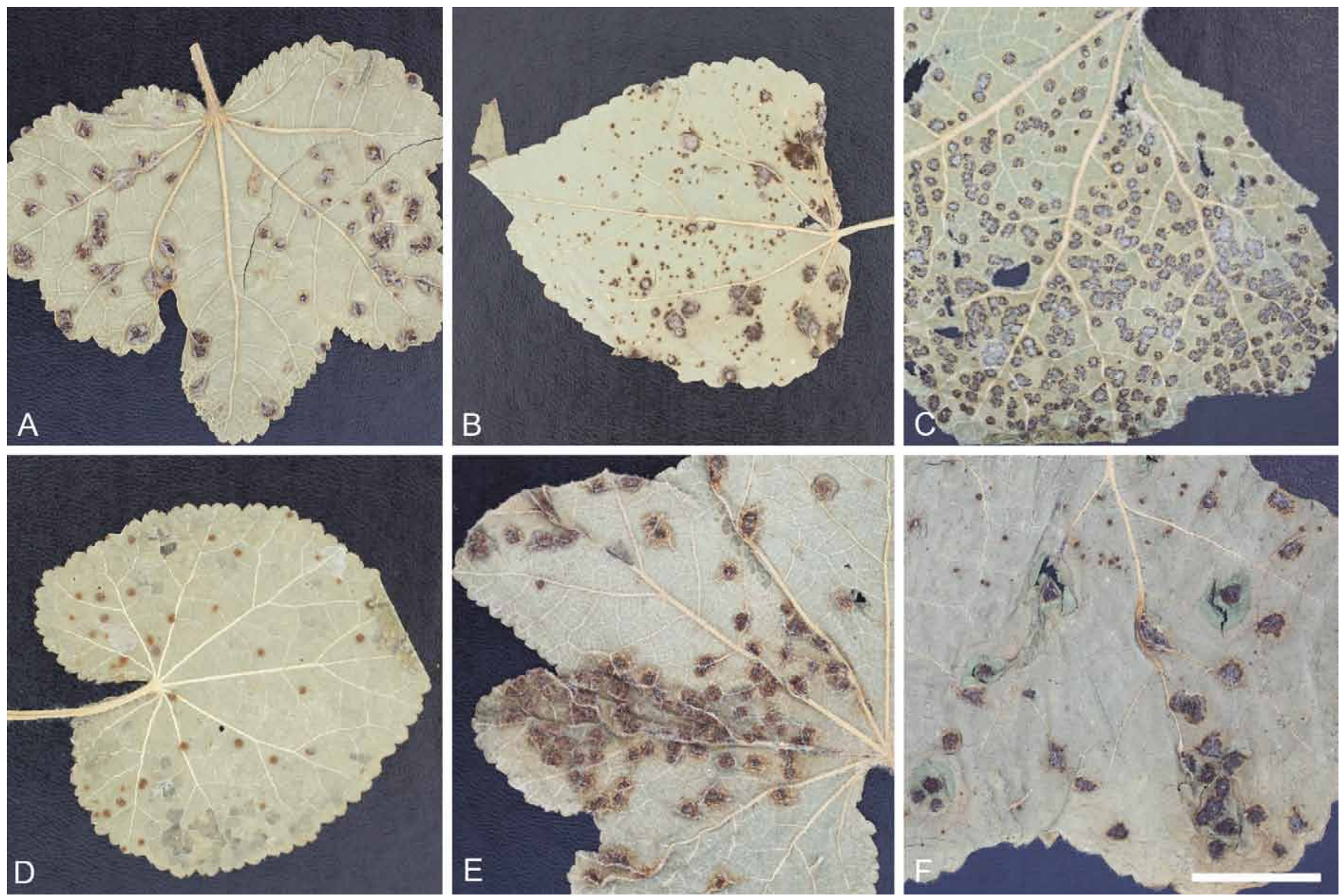

Fig. 2. Macroscopic features. A. Puccinia heterogenea (BPI 074083 - holotype). B. Puccinia heterospora (BPI 074275). C. Puccinia lobata (BPI 081381). D. Puccinia malvacearum (BPI 074281). E. Puccinia platyspora (BPI 841116). F. Puccinia sherardiana $(\mathrm{BPI} 102200)$. Bar $=2 \mathrm{~cm}$.

spores mixed, one-celled spores predominating in most samples. One-celled teliospores 24-57 × 15-34 $\mu \mathrm{m}$, on average $32 \times 21 \mu \mathrm{m}$. Two-celled teliospores $28-57 \times 15-$ $34 \mu \mathrm{m}$, on average $42 \times 24 \mu \mathrm{m}$. Side walls of teliospores 2-3 $\mu \mathrm{m}$ thick, apical walls $2-5 \mu \mathrm{m}$ thick. Pedicels hyaline, to $140 \mu \mathrm{m}$ long.

Specimens examined: Ecuador: Quito, on Alcea rosea, Nov. 1890, G. Lagerheim (BPI 074083 - holotype). - Intercepted specimens (origin unknown): Intercepted at Miami, Florida, entering from Ecuador, on Malva arborea, 9 Mar. 1967, P. R. Whitley (BPI 074394); Intercepted at Miami, Florida, entering from Ecuador, on Malva arborea, 5 Aug. 1967, J. Bache-Wiig (BPI 074393); Intercepted at Los Angeles, California, entering from Ecuador, on Malva arborea, 9 Aug. 1986, R. Heliczer (BPI 1107917); Intercepted at Atlanta, Georgia, entering from Ecuador, on Malva arborea, 14 Aug. 2010, M. Burgos (BPI 893206); Intercepted at Miami, Florida, entering from Ecuador, on Malva arborea, 12 Mar. 2013, J. E. Lopez (BPI 893204); Intercepted at Miami, Florida, entering from Ecuador, on Malva arborea,13 Mar. 2013, M. Polanco (BPI 893205); Intercepted at Miami, Florida, entering from Ecuador, on Malva arborea, 5 Jul. 2014, L. Pizarro (BPI 893207); Intercepted at Miami, Florida, entering from Jamaica, on Malva arborea, 13 Aug. 2014, D. B. Leimer (BPI 893208).

Puccinia malvacearum Bertero ex Mont., Hist. fis. $y$ polit. Chile 8: 43 (1852).

(Figs 2-3)
Description: Telia light reddish brown, mainly hypophyllous, scattered. Teliospores yellowish brown, often with apical pores or split walls at the apices; most specimens predominately with two-celled spores, but some with predominately one-celled spores. One-celled teliospores 30-54 × 14-24 $\mu \mathrm{m}$, on average $42 \times 18 \mu \mathrm{m}$. Two-celled teliospores 29-82 × 12-32 $\mu \mathrm{m}$, on average $51 \times 21 \mu \mathrm{m}$, Side walls of teliospores $1-4 \mu \mathrm{m}$ thick, apical walls 3-7 $\mu \mathrm{m}$ thick. Pedicels hyaline, to $130 \mu \mathrm{m}$ long.

Specimens examined: Intercepted specimens (origin unknown): Intercepted at Chicago, Illinois, entering from Israel, on Malva nicaeensis, 11 Mar. 2004, N. A. Jarrett (BPI 893202); Intercepted at Hoboken, New Jersey, entering from The Netherlands, on Alcea rosea, 25 Jan. 2005, P. Milicia (BPI 893199); Intercepted at San Luis, Arizona, entering from Mexico, on Malva neglecta, 29 May 2010, C. G. Vazquez (BPI 893201); Intercepted at Boston, Massachusetts, entering from Portugal, on Malva multiflora, 21 May 2013, B. Nichols (BPI 893200); Intercepted at San Ysidro, California, entering from Mexico, on Alcea sp., 23 Feb. 2015, A. Ashley (BPI 893197). - USA: California: Stanford, on M. arborea var. variegata, 7 Apr. 1926, J. W. Gillespie (BPI 082182); California: Felton, on M. arborea var. variegata, 26 Apr. 1948, N. R. Hunt (BPI 082183); Oregon: Linn Co., Corvallis, on M, sylvestris, 12 Sep. 1997, R. R. Halse (BPI 806271).

Puccinia lobata Berk. \& M. A. Curtis, Grevillea 3: 54 (1874).

(Figs 2-3) 


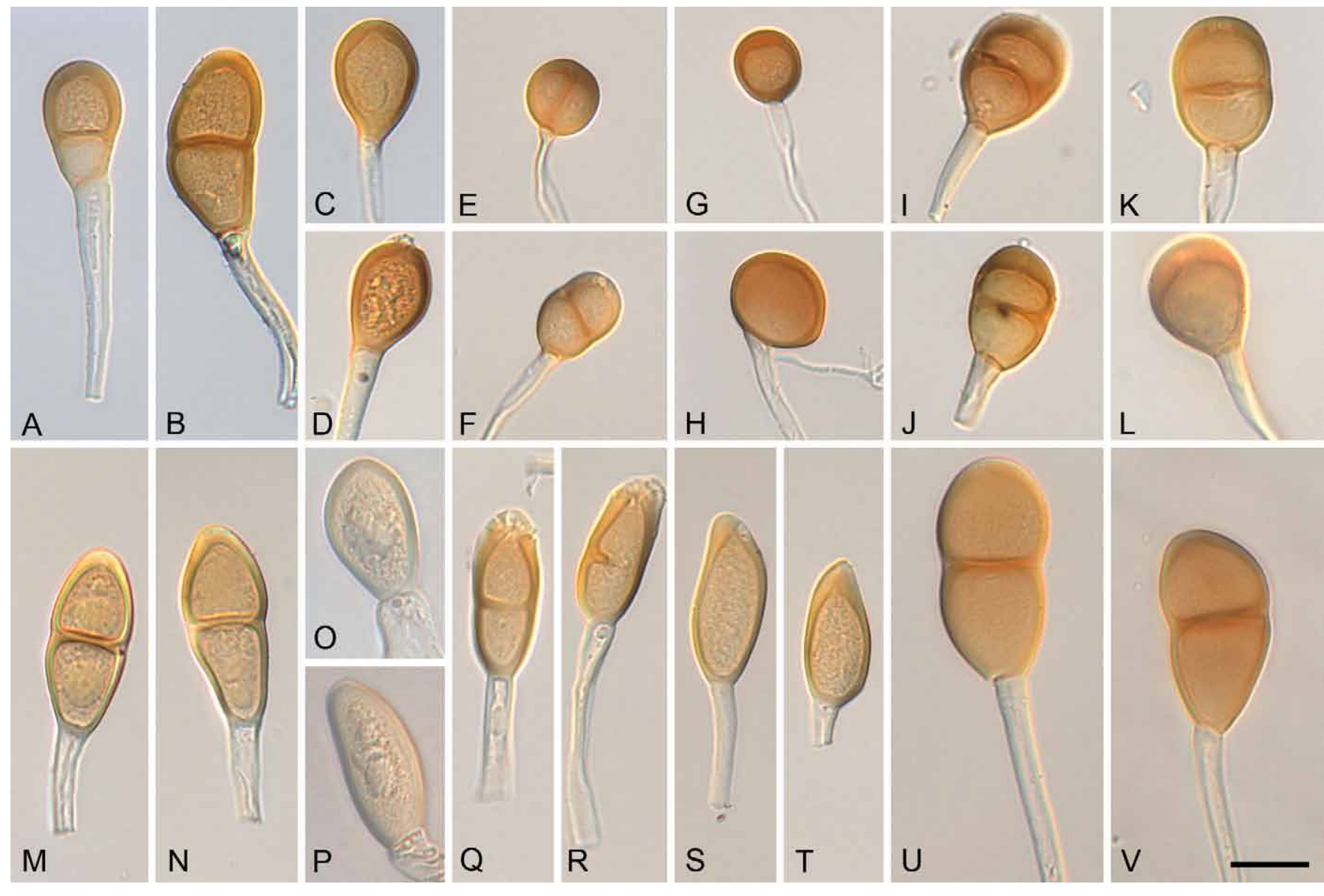

Fig. 3. Teliospores. A-D. Puccinia heterogenea. A, B. Two-celled teliospores (BPI 074393). C, D. One-celled teliospores (BPI 074393, BPI 893208). E-H. Puccinia heterospora. E. Two-celled teliospore with septum perpendicular to pedicel attachment point (BPI 074283). F. Twocelled teliospore (BPI 074283). G. One-celled teliospore (BPI 074283). H. Large one-celled teliospore (BPI 863576). I-L. Puccinia lobata. I-K. Two-celled teliospores (BPI 081369, BPI 081369, BPI 018413). L. One-celled teliospore (BPI 081369). M-P. Puccinia malvacearum. M, N. Twocelled teliospores (BPI 893197). O, P. One-celled teliospores (BPI 893199). Q-T. Puccinia platyspora. Q. Two-celled teliospore (BPI 841116). R. Two-celled teliospore with partial septum (BPI 841116). S, T. One-celled teliospores (BPI 091376, BPI 841116). U, V. Puccinia sherardiana. U, V. Two-celled teliospores (BPI 102198). Bar $=20 \mu \mathrm{m}$.

Description: Telia dark brown, hypophyllous, in tight clusters. Teliospores yellowish brown, often with apical pores or split walls at the apices, predominately two-celled. One-celled teliospores $26-31 \times 21-25 \mu \mathrm{m}$, on average $28 \times 24 \mu \mathrm{m}$. Twocelled teliospores $25-40 \times 16-27 \mu \mathrm{m}$, on average $32 \times 22$ $\mu \mathrm{m}$. Side walls of teliospores $1.5-3 \mu \mathrm{m}$ thick, apical walls 5-10 $\mu \mathrm{m}$ thick in one-celled spores and 4-9 $\mu \mathrm{m}$ thick in twocelled spores. Pedicels hyaline, to $120 \mu \mathrm{m}$ long.

Specimens examined: Intercepted specimens (origin unknown): Intercepted at Laredo, Texas, entering from Mexico, on Malvella lepidota, 26 May 1966, G. E. Reuthinger (BPI 081413). - USA: Texas: Presidio, on Alcea rosea, 23 Nov. 1955, J. H. Russell (BPI 081369). Texas: Corpus Christi, on A. rosea, 28 May 1966, C. M. Locke (BPI 081379).

Puccinia sherardiana Körn., Hedwigia 16: 19 (1877). (Figs 2-3)

Description: Telia dark brown, hypophyllous, in tight clusters. Teliospores light brown, often with apical pores or split walls at the apices, predominately two-celled. One-celled teliospores 34-36 × 18-30 $\mu \mathrm{m}$, on average $35 \times 24 \mu \mathrm{m}$. Twocelled teliospores 34-60 × 17-34 $\mu \mathrm{m}$, on average $47 \times 25$ $\mu \mathrm{m}$. Side walls of teliospores 1.5-3 $\mu \mathrm{m}$ thick, apical walls $3-7$ $\mu \mathrm{m}$ thick. Pedicels hyaline, to $200 \mu \mathrm{m}$ long.

Specimens examined: Intercepted specimens (origin unknown): Intercepted at EI Paso, Texas, entering from Mexico, on Sphaeralcea sp., 30 Nov. 2004, R. A. Garner-Lozoya (BPI 871782); Intercepted at El Paso, Texas, entering from Mexico, on Sphaeralcea sp., 8 Dec. 2004, J. Gasca (BPI 871783). - USA: Colorado: Las Animas Co., Trinidad, on Alcea rosea, 4 Sep. 1965, J. A. Parmalee \& D. I. Hammond, (BPI 102198).

\section{DISCUSSION}

Multiple rust fungi can infect plants in Malveae, and plants from this tribe imported into the USA are often intercepted with visible rust disease, generally caused by Puccinia malvacearum and $P$. heterogenea. Puccinia malvacearum has been reported to have a much wider geographical distribution than P. heterogenea (Farr \& Rossman 2015). The exact origin 
of many of the specimens in this study is, however, uncertain because they were intercepted from luggage and cargo and may have been extensively moved during travel and trade. The reported origins of the intercepted $P$. malvacearum specimens include Israel, Mexico, The Netherlands, and Portugal, with additional specimens with verified origins from the USA, agreeing with the reported worldwide distribution of $P$. malvacearum. In contrast, all intercepted $P$. heterogenea specimens were reported as originating from Ecuador, except for one reported as from Jamaica, which was possibly not its true origin. Puccinia heterogenea has only been previously reported from Ecuador and Peru (Farr \& Rossman 2015), and the samples collected in this study suggest that it has not spread further.

Puccinia malvacearum has been intercepted on many species of plants and is reported to have a very large host range in Malvoideae (Farr \& Rossman 2015). This study focused on intercepted rust fungi of Malveae, especially Alcea rosea, so a comprehensive survey of other possible hosts of $P$. malvacearum was not completed. In this limited sampling, $P$. malvacearum was detected on $A$. rosea and several Malva species. Puccinia heterogenea is reported on a much smaller host range than $P$. malvacearum, only $A$. rosea and various Malva species (Farr \& Rossman 2015). In this study, $P$. heterogenea was mainly detected on plants identified based on ITS sequences as Malva arborea, tree mallow. Tree mallow is considered medicinal (Germplasm Resources Information Network; http://www.ars-grin.gov/ cgi-bin/npgs/html/taxon.pl?455281), so it is more likely to be imported and intercepted than other, less ethnobotanically useful, hosts of $P$. heterogenea.

The other four microcyclic Puccinia species reported on $A$. rosea are $P$. heterospora, $P$. lobata, $P$. platyspora, and $P$. sherardiana. Sequencing a representative sample of each confirmed that they are different from both $P$. malvacearum and $P$. heterogenea. These rusts are morphologically similar and may be confused with each other, as well as with other Puccinia species on malvaceous plants such as $P$. anodae, $P$. exilis, $P$. modiolae, $P$. sidalceae, and $P$. sphaeralceae. Puccinia heterospora, P. lobata, P. platyspora, and $P$. sherardiana appear to have wide host ranges like $P$. malvacearum, as all four were found on hosts not closely related to A. rosea (Escobar García et al. 2009): Sphaeralcea for $P$. platyspora and $P$. sherardiana; Malvella for P. lobata; and Abutilon, Anoda, and Sida for P. heterospora - although the high degree of intraspecific variation in $P$. heterospora raises the possibility that it is composed of cryptic species with smaller, more specific host ranges. As with $P$. heterogenea, $P$. heterospora, P. lobata, $P$. platyspora, and $P$. sherardiana have a smaller reported geographic distribution than $P$. malvacearum. $P$. heterospora has been reported worldwide except for Europe, $P$. lobata and $P$. sherardiana have been reported in North and South America, and $P$. platyspora has been reported only in South America (Farr \& Rossman 2015). Although $P$. platyspora and $P$. heterogenea have not been reported in the US, and $P$. lobata and $P$. sherardiana have only been reported in the western US, their similarity to $P$. malvacearum suggests that they would not cause more damage than $P$. malvacearum if spread to new areas and that they could be similarly managed. The study of intercepted fungi can provide useful information about their biology, systematics, and long-distance movement in trade.

\section{ACKNOWLEDGEMENTS}

We thank Cathie Aime for the use of DNA sequences, the US National Fungus Collections for access to reference material, and Tunesha Phipps for technical support.

\section{REFERENCES}

Arthur JC (1922) Uredinales. North American Flora 7: 481-540.

Arthur JC (1934) Manual of the Rusts in United States and Canada. Lancaster, PA: Science Press.

Baum DA, DeWitt Smith S, Yen A, Alverson WS, Nyffeler R, et al. (2004) Phylogenetic relationships of Malvatheca (Bombacoideae and Malvoideae; Malvaceae sensu lato) as inferred from plastid DNA sequences. American Journal of Botany 91: 1863-1871.

Chen S, Yao H, Han J, Liu C, Song J, et al. (2010) Validation of the ITS2 region as a novel DNA barcode for identifying medicinal plant species. PLoS One 5: e8613.

Escobar García P, Schönswetter P, Fuertes Aguilar J, Nieto Feliner G, Schneeweiss GM (2009) Five molecular markers reveal extensive morphological homoplasy and reticulate evolution in the Malva alliance (Malvaceae). Molecular Phylogenetics and Evolution 50: 226-239.

Farr DF, Rossman AY (2015) Fungal Databases. Beltsville, MD: Systematic Mycology and Microbiology Laboratory, ARS, USDA; http://nt.ars-grin.gov/fungaldatabases/.

Katoh K, Standley DM (2013) MAFFT multiple sequence alignment software version 7: improvements in performance and usability. Molecular Biology and Evolution 30: 772-780.

Lindquist JC (1982) Royas de la Republica Argentina y Zonas Limitrofes. Buenos Aires: Instituto Nacional de Technologia Agropecuaria (INTA).

McCullough DG, Work TT, Cavey JF, Liebhold AM, Marshall D (2006) Interceptions of nonindigenous plant pests at US ports of entry and border crossings over a 17-year period. Biological Invasions 8: 611-630.

Stamatakis A, Hoover P, Rougemont J (2008) A rapid bootstrap algorithm for the RAxML web-servers. Systematic Biology 57: 758-771.

Vilgalys R, Hester M (1990) Rapid genetic identification and mapping of enzymatically amplified ribosomal DNA from several Cryptococcus species. Journal of Bacteriology 172: 4238-4246.

White TJ, Bruns T, Lee S, Taylor J (1990) Amplification and direct sequencing of fungal ribosomal RNA genes for phylogenetics. In: PCR Protocols: a guide to methods and mpplications (Innis MA, Gelfand DH, Sninsky JJ \&White TJ, eds): 315-322. San Diego: Academic Press. 